\title{
Association of household income and female labour force participation rate in income generating activities in hill rural areas of Uttarakhand
}

\author{
Prashant Kandari ${ }^{1}$ and Uma Bahuguna ${ }^{2}$ \\ ${ }^{1}$ Department of Economics, H.N.B. Garhwal Central University, Srinagar Garhwal, Uttarakhand \\ ${ }^{2}$ Department of Sociology, H.N.B. Garhwal Central University, Srinagar Garhwal, Uttarakhand
}

\author{
*Corresponding Author Email: kandari1980@gmail.com
}

Received: 10.08.2019; Revised: 24.10.2019; Accepted: 3.11.2019

OSociety for Himalayan Action Research and Development

\begin{abstract}
As per 2011 Census, about 70 per cent of population in Uttarakhand state resides in rural areas and the ten hill districts out of total 13 districts of the State comprises 48.1 per cent of its entire population. Difficult terrain, lack of transport, lack of employment due to non availability of industrial sector along with small farm sizes and low farm incomes has fuelled large migration from these hill rural areas of the Uttarakhand to the urban regions across the country. The various studies reflect upon the importance of women in the economy of the hill areas as they share the burden of their families and their participation in employment and subsistence cum income generating activities mainly in the rural regions is much higher than the males. The importance of women further enhances amidst the severe problem of migration of males and mainly of the youths from these regions to the urban areas. The women are left back to work in most tough conditions further taking care of the domestic chores. The females labour force participation is higher in rural areas of the state, as per National Sample Survey Office, 68th Round, the female labour force participation rate in rural areas was 31.5 percent and 10.8 percent in urban areas of the state. In this context it is very important to understand the nature of female labour force participation i.e. , whether it is in non-income generating sector like agriculture or in purely income generating sector which mainly comprises of both i.e., agriculture and non-agriculture sector. The present study analyses this distribution of female labour force participation and depicts the association between the female labour force participation in income generating activities and the total household income.
\end{abstract}

Key words: Female labour force, Participation rate, Agriculture, Hill Rural areas, Income generating activities, Household income

\section{Introduction}

Deprivation of an area enhances the vulnerability of the most deprived and dependent sections of the society. Area deprivation leads to economic and social deprivation for the inhabitants of such areas. While the economic deprivation is the lack of economic choices, on the other hand the social deprivation is the lack of social independence, freedom and mobility. The social aspect of deprivation prevails due to the existence of economic deprivation as it hinders the social interaction and association between an individual unit and the society in large. On the other side the economic deprivation leads to social exclusion which is a result of low education, poor living standard, mental and physical illness and low socio-economic status. The impact of low economic status alongside poor social status although borne by every sections but its greater impact is largely borne by the marginalized groups like females and low caste status community. Women of these areas even though carrying the burden of all the problems associated with these regions play a vital role in the economy of these regions. The participation of the women in the agriculture and allied activities is significantly large in comparison to males; further the increasing migration of males to the urban areas, mainly the youths has over burdened the women of 
these areas. The large scale out-migration of men in search of employment in the plains or in the army has led to a demographic imbalance in the region. While men predominate in urban areas, the interior rural districts are amongst the few in all of India that contain significant woman majorities (Rawat, 2004). Apart from converting hill economy into money order economy, migration by the male population has also given rise to various social and psychological problems among the hill women. Due to the prevailing social customs and traditions, women are often mistreated by relatives, which at times get so serious that it has led to cases of women committing suicide (Dighe, 2008). When men migrate to cities, apart from the domestic chores of cooking, fetching fuel, fodder and water, looking after children, the tasks of caring for livestock and agricultural work also fall on women's shoulders. Since agricultural fields are located on terraces in the hilly region and are generally very small, modern agricultural implements cannot be used. As a result, agricultural work becomes highly time-consuming, thus increasing women's workload tremendously. Men prefer to do less time-consuming work which requires less labor, and generates more and quick money. They do not show much interest in routine agricultural work because it requires hard labor and is less productive. Therefore, instead of sharing the work with women, they prefer to migrate to urban areas (Nautiyal, 2003).

\section{The Research Problem}

The various studies clearly indicate towards a very high labour force participation rate in rural areas of Uttarakhand. This is indicative of larger participation of females in economic activities which makes them essential component of the economy of these regions of the state. Many factors could be attributed to this trend, the prominent one is the large scale migration of males and secondly the agriculture land ownership pattern among the rural households in these hill regions of the state. The high female labour force participation is generally one of the indicators of economic empowerment but prior to assume that it is utmost important to study the nature of female labour force participation. In the present context the nature of participation signifies that whether the female labour force participation is in income generating employment activities or is in non-income generating employment activities (unpaid work which is other than household domestic chores). The non-income generating activities largely comprise of the agriculture activities which are largely carried out for meeting out the subsistence household demand. The pattern of female labour force participation in these deprived regions of the state suggests that it is largely in subsistence generating areas rather than in income generating areas. Further various studies have shown the relationship between the household income and female labour force participation. But in the present context keeping the dimension of economic empowerment in priority we have analyzed the same relationship in respect of household income and female labour force participation only in income generating activities.

But even in the aforementioned aspect the role of female in the economy of rural areas of hill regions could not be underestimated. Majority of females are engaged in non-income generating activities such as in agriculture which is carried out to meet the domestic consumption demand and often such type of work gets ignored in various official surveys. But it is important to mention that such work hold prime importance in these regions as such activities not only sustains the food demand of the households but also works as a buffer system in adverse economic situations.

\section{Research Methodology and Study Area}

The population for the purpose of the study comprises of females belonging to rural hill areas belonging to all castes (SC, ST, OBC, Others), all religions and all Income groups (Antyodaya, BPL, APL, others) of the three hill districts of Uttarakhand which are Pauri, Rudraprayag and Chamoli districts. For the present study out of total 15 blocks in Pauri district, 10 development blocks were randomly selected. From Chamoli districts out of 9 development blocks, 5 blocks were selected and further from Rudraprayag district out of 3 
blocks 2 blocks were selected for the present study. A total of 51 villages were randomly selected for the study and from each village a total of 20 households were randomly selected for the study. Thus a total of 1020 households were selected for the present study. A total of 1705 female from these households were selected which were in working age group and which were either engaged in various employment activities or were willing to work. Both primary and secondary data were collected for the study but the major emphasis was given to the collection of primary data.

\section{Research Findings}

Among the 1020 households a total of 1705 females belonging to working age group were studied who were engaged in employment activities or were willing to work. Out of a total of 1705 females a total of 756 females were engaged in various income generating activities and 622 females were engaged in nonincome generating employment activities while 327 females were not engaged in any activity but were willing to work and thus comprises the labour force. A total of 756 females were engaged in one form of income generating employment activity and 71 females among them were engaged in one and more than one form of income generating employment activity in these regions.

\section{Employment status of hill rural women}

Uttarakhand women have always emerged as the pillars of the rural economy due to their total involvement with agriculture, forest protection, cattle care and dairying. Women contribute productive work force in the economy of these hill rural regions of Uttarakhand state. Women form the backbone of agriculture, in these deprived regions of the state. Due to the huge migration of males almost all the different agriculture activities are now carried out by the females of these regions. Apart from being largely involved in the agriculture activities the females of these regions have actively started to participate in the non-agricultural activities. The following table depicts the participation of hill rural females in the employment activities.

Table No: 1 Distribution of working age population of females who were working or were willing to work in both income generating and non-income generating activities

\begin{tabular}{|c|c|}
\hline Income generating and employment status of females & No. of females \\
\hline Not earning and non engaged in any employment activity but willing to work & 327 \\
\hline Engaged in non-income generating employment activity & 622 \\
\hline Earning from one employment activity & 756 \\
\hline Earning from more than one employment activity & 71 \\
\hline
\end{tabular}

Source: (Primary survey Nov, 2017-Aug, 2018)

Table No: 2 Field of employment among the females

\begin{tabular}{|c|c|c|c|}
\hline S.No & Field of employment & No. of females & Percentage of female \\
\hline 1 & Agriculture & 1149 & 67.3 \\
\hline 2 & Animal husbandry & 310 & 18.2 \\
\hline 3 & Casual Wage labour & 500 & 29.3 \\
\hline 4 & Main Worker & 71 & 4.2 \\
\hline 5 & Self employment & 72 & 4.2 \\
\hline 6 & None & 327 & 19.2 \\
\hline
\end{tabular}

\section{*Some of the females are engaged in more than one field of employment}

Source: (Primary survey Nov, 2017-Aug, 2018)

The above data depicts that majority of the female labour force participation in these hill rural regions is in the agriculture and allied activities. Another major sector which employs a large percentage of female 
in employment is the informal sector which comprises of the work as casual wage labour. Majority of this work comprises of the employment generated by MNREGA. Study shows that about 30 percent of the females in these regions are working as casual wage worker. A marginal percentage of females are working as main worker i.e. as salaried employee. The concerning issue is that self employment has failed to become a major source of employment generation for the females of these regions. Only about 4 percent of females are participating in this form of employment.

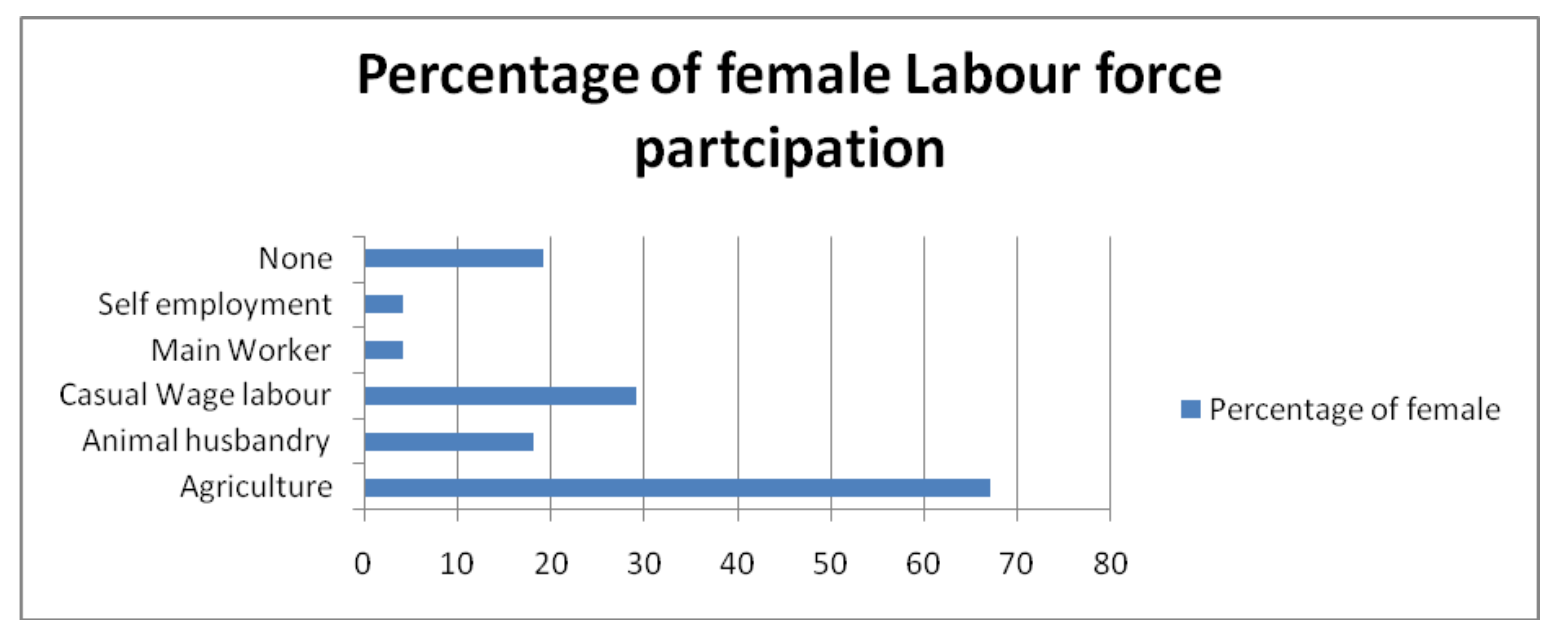

Fig: 1 Percentage of female labour force participation in employment activities

Source: (Primary survey Nov, 2017-Aug, 2018)

The overall analysis of the female labour force participation depicts their larger participation in the informal sector activities among which agriculture and allied sector is the major employment generator. The observation of higher female labour force participation in agriculture also reflects upon the higher work pressure on them which ranges from light to very heavy work putting a major toll on their health. Of the above mentioned activities in which the females are involved not all activities generates income for the females. Many of these activities are carried out to earn subsistence in form another than in monetary form. Keeping this fact in perspective the study analyzed the female participation in employment activities in terms of their capabilities to earn income out of it. The results of the study are as follows.

Table No: 3 Source of income/Wage generative employment

\begin{tabular}{|c|l|c|c|}
\hline S.No & \multicolumn{1}{|c|}{ Field of employment } & $\begin{array}{c}\text { No. of } \\
\text { females }\end{array}$ & $\begin{array}{c}\text { Percentage of female } \\
\text { participation }\end{array}$ \\
\hline 1 & Agriculture & 104 & 5.2 \\
\hline 2 & Animal husbandry & 80 & 4.0 \\
\hline 3 & Casual Wage labour & 500 & 25.1 \\
\hline 4 & Salaried employee & 71 & 3.6 \\
\hline 5 & Self employment & 72 & 3.6 \\
\hline 6 & $\begin{array}{l}\text { Engaged in non-income generating employment } \\
\text { activities or are not earning but willing to work }\end{array}$ & 949 & 47.6 \\
\hline
\end{tabular}

Source: (Primary survey Nov, 2017-Aug, 2018) 
*Note: Some of the females are deriving income from more than one field of employment which makes the total of 827 females in income earning category which is 71 higher than the actual number of females i.e. 756 which are actually engaged in income earning activities

The analysis of the females participation in the income/wage generating employment indicates that majority of the females in these regions are engaged in agriculture. Participation of females in the income generating activities is higher in the non-agricultural activities among which the majority of females are working as marginal worker or casual wage worker. In the study it was observed that majority of the females in these hill rural regions are engaged in work generated through MNREGA. Study suggests that huge percentages i.e. about 48 percent of the females in these regions are engaged in non-income generating employment activities or are not earning or employed in any activity but willing to work which suggest the existence of involuntary unemployment among females in these regions of the state.

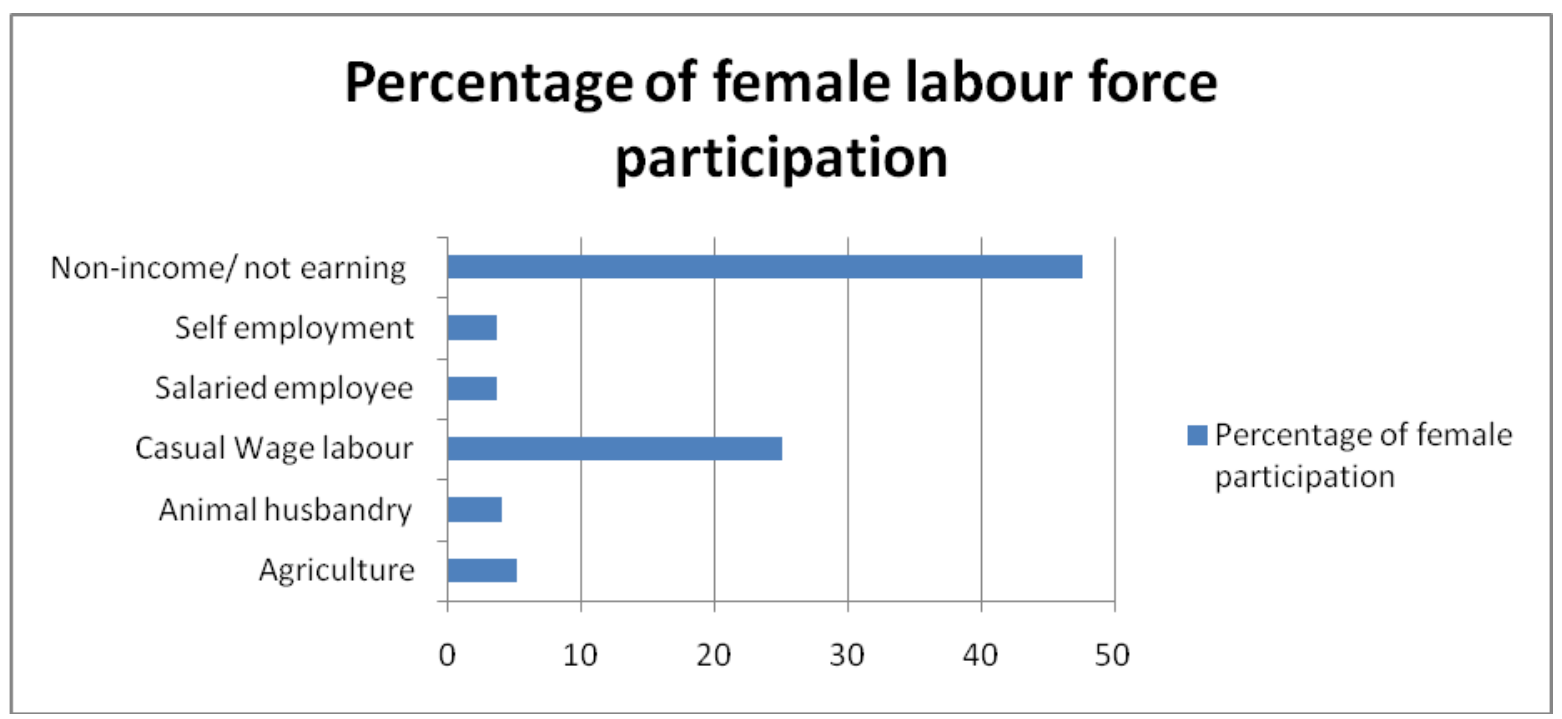

Fig No: 2 Percentage of female participation in income generating employment activities Source: (Primary survey Nov, 2017-Aug, 2018)

\section{Income contributed by females in total household income}

The study has shown that the hill rural female income contribution to total household income is relatively less than that of males. Keeping this aspect in priority the study analyzed the contribution of females earned income in the overall income of the family. The results of the study are as follows:

Table No: 4 Distribution of income contributed by females in the total household income

\begin{tabular}{|c|c|c|}
\hline $\begin{array}{c}\text { Percentage of income contributed } \\
\text { by females }\end{array}$ & No. of females & Percentage \\
\hline $0-20$ & 97 & 12.8 \\
\hline $21-40$ & 178 & 23.5 \\
\hline $41-50$ & 247 & 32.7 \\
\hline $51-60$ & 95 & 12.6 \\
\hline $61-80$ & 71 & 9.4 \\
\hline $81-100$ & 68 & 9.0 \\
\hline Total & 756 & 100 \\
\hline
\end{tabular}

Source: (Primary survey Nov, 2017-Aug, 2018) 
The study shows that about majority of females i.e. about 33 percent, in these regions are contributing about 41 to 50 percent of the total of their family income. About 20 percent of females are contributing about 21 to 40 percent of the total of their family income. About 30 percent of females in these regions are contributing more than 50 percent towards their total family income. All these results indicate that females along with contributing in non-income generating employment activities are also contributing significantly in total household income and thus are significant bread earners for their families in these regions.

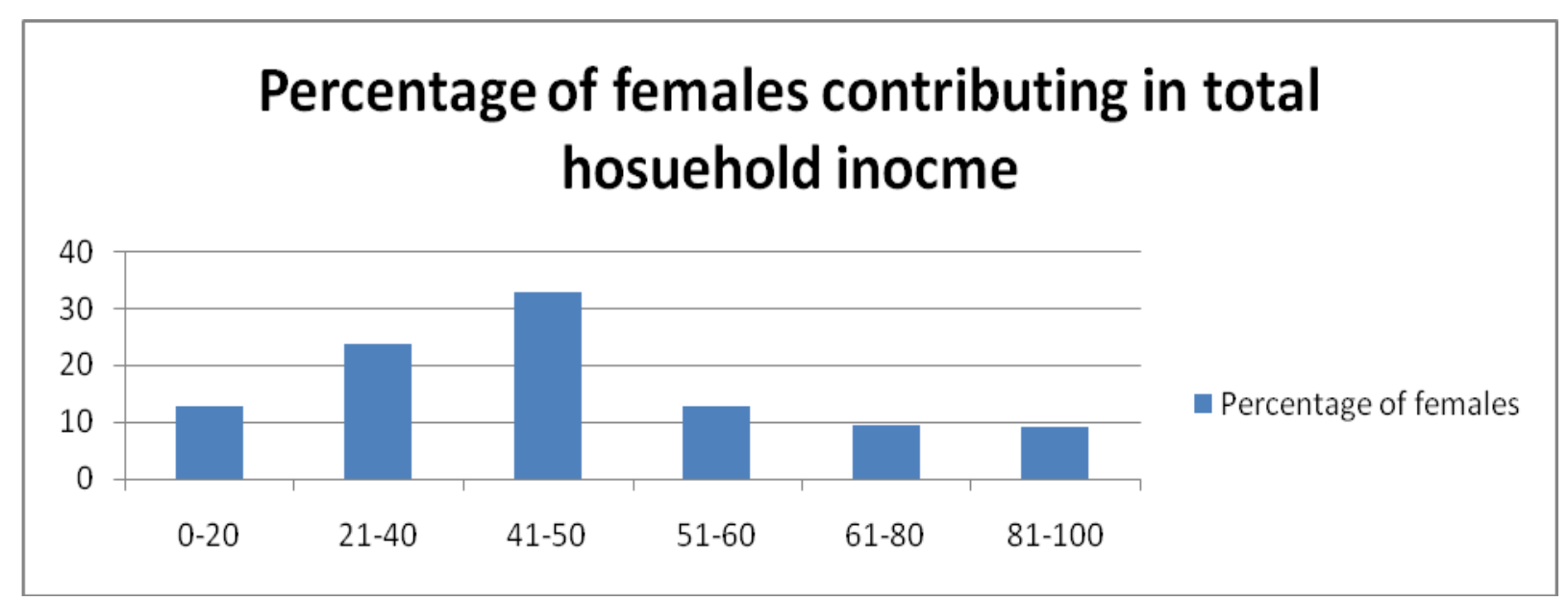

Fig No: 3 Percentage of income contributed by females engaged in employment activities Source: (Primary survey Nov, 2017-Aug, 2018)

Table No: 5 Distribution of Female labour force participation rate in income generating activities at different household income levels

\begin{tabular}{|c|c|c|c|}
\hline $\begin{array}{c}\text { Average income } \\
\text { Range }\end{array}$ & $\begin{array}{c}\text { Working female } \\
\text { (income generation) }\end{array}$ & $\begin{array}{c}\text { Total females in } \\
\text { working age group }\end{array}$ & Female participation rate \\
\hline Upto Rs. 1000 & 4 & 81 & 0.049383 \\
\hline 1001 to 2000 & 112 & 123 & 0.910569 \\
\hline 2001 to 3000 & 87 & 154 & 0.564935 \\
\hline 3001 to 4000 & 96 & 275 & 0.349091 \\
\hline 4001 to 5000 & 78 & 171 & 0.45614 \\
\hline 5001 to 6000 & 61 & 152 & 0.401316 \\
\hline 6001 to 7000 & 51 & 153 & 0.333333 \\
\hline 7001 to 8000 & 44 & 85 & 0.517647 \\
\hline 8001 to 9000 & 57 & 77 & 0.74026 \\
\hline 9001 to 10000 & 38 & 101 & 0.376238 \\
\hline 10001 to 11000 & 35 & 71 & 0.492958 \\
\hline 11001 to 12000 & 44 & 62 & 0.709677 \\
\hline 12001 to 13000 & 18 & 49 & 0.367347 \\
\hline 13001 to 14000 & 7 & 57 & 0.122807 \\
\hline 14001 to 15000 & 9 & 45 & 0.2 \\
\hline 15001 and above & 15 & 49 & 0.306122 \\
\hline & 756 & 1705 & \\
\hline
\end{tabular}

Source: (Primary survey Nov, 2017-Aug, 2018) 
Testing: The relationship between female participation rate of the females engaged only in income generating activities and household income

Various studies have shown the u-shape probability curve relationship between the rural women's paid labour force participation rate and household consumption expenditure. To test this fact due to unavoidable research constraints such as respondent illiteracy, respondents reluctance to reveal the information and unclear information, instead of household consumption expenditure we have used utilized household average monthly income and compared it with the females participation rate in labour force of only the females who are engaged in income generating employment activities. The results of the analysis are as follows:

Table 5 reveals the women labour force participation rate (engaged in income generating activities) at different income levels of households in these hill rural areas. To study this association more clearly, we have utilized figures for more clearly depicting this relationship. Following chart presents the same relationship with the help of a curve.

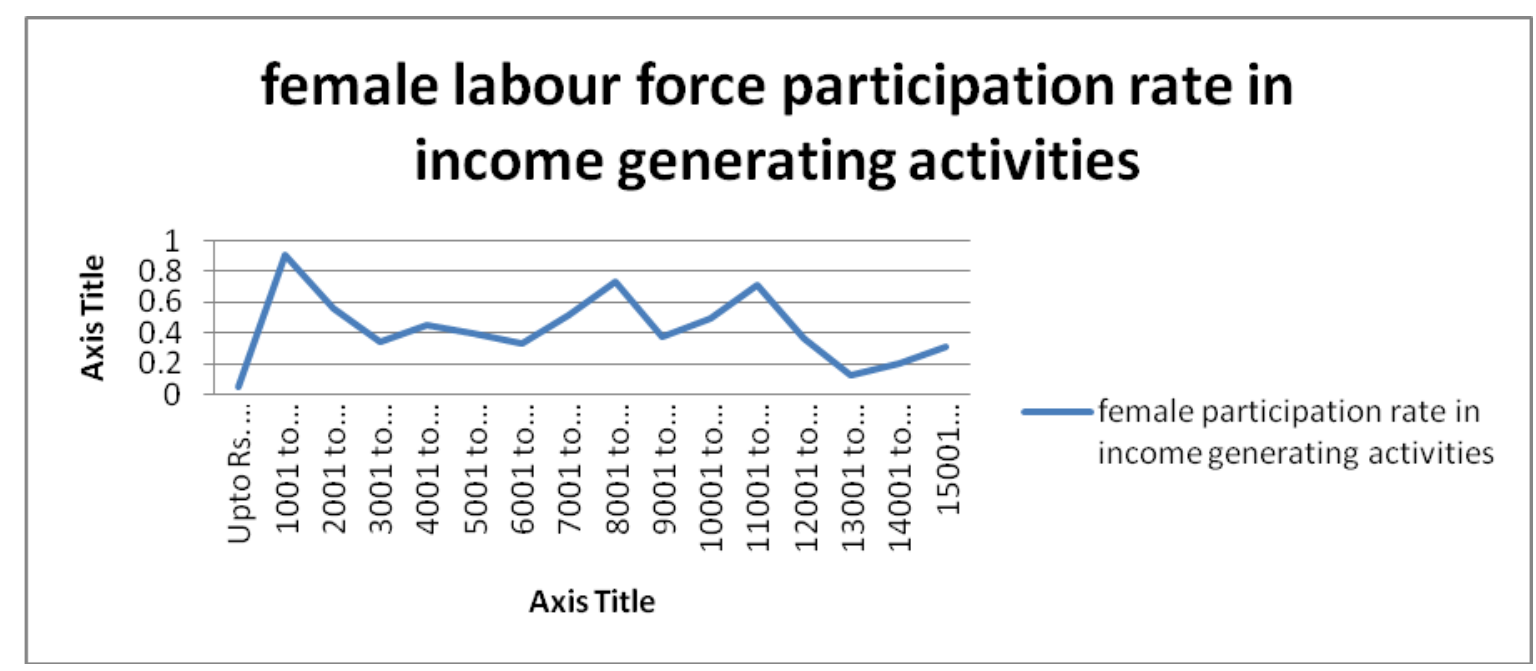

Fig No: 4 Female labour force participation rate in income generating activities at different household income levels

Source: (Primary survey Nov, 2017-Aug, 2018)

The above figure clearly depicts the highly skewed data related to the paid women labour force participation rate at different income levels of households in the hill rural areas. To analyze the underlying trend in the above data we have produced a similar figure of the same relationship which also includes a trend line for the same curve.

The trend line observed in the above figure clearly indicates towards the falling female participation rate in income generating activities with increase in the income levels of the rural households. This falling trend further indicates towards the push lead female labour force participation in income generating activities in the case of households with lower levels of income. This push led female participation is largely in the non-agriculture informal sector and is mainly represented by females working as casual worker or marginal workers. 


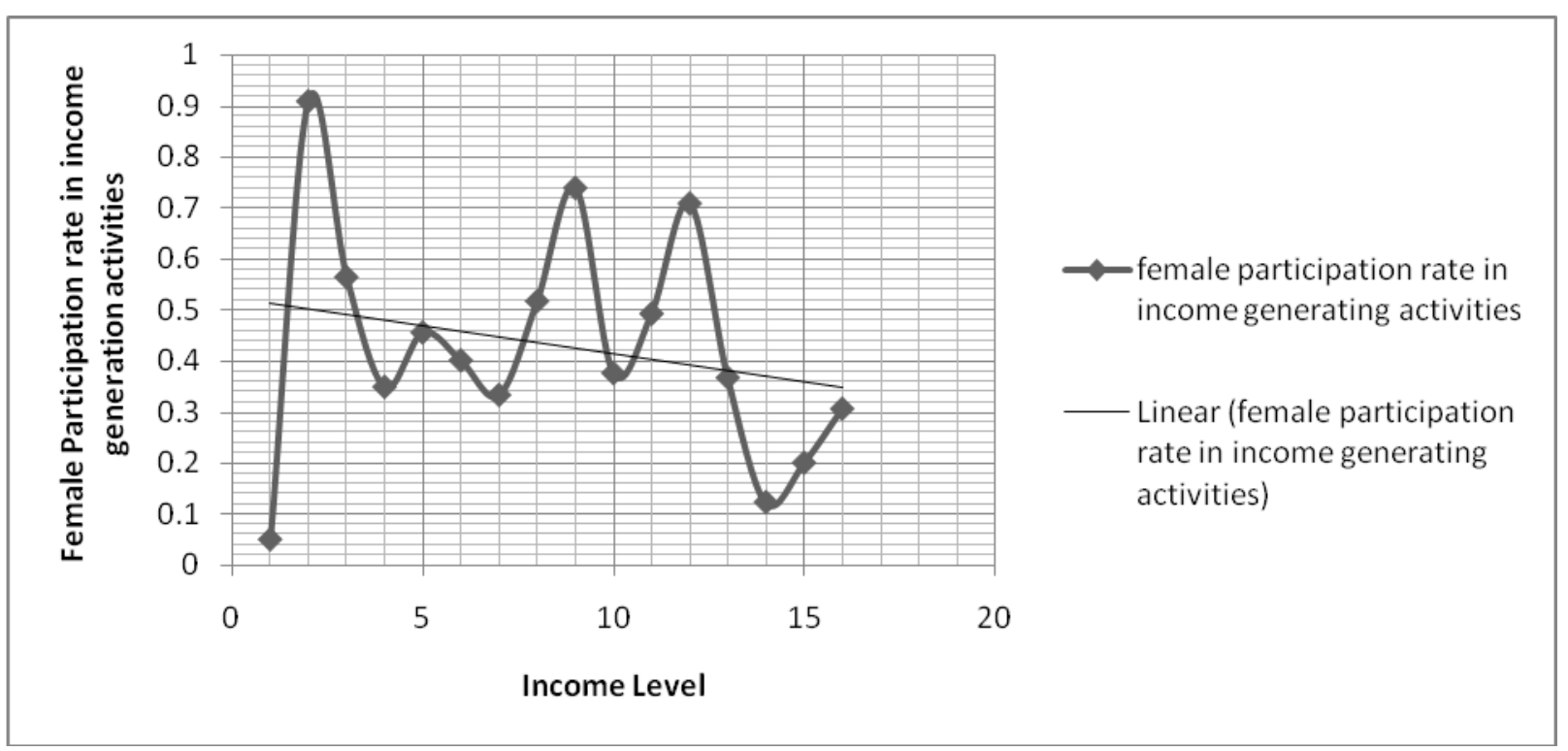

Fig No: 5 Female labour force participation rate in income generating activities at different household income levels (Trend line)

Source: (Primary survey Nov, 2017-Aug, 2018)

\section{Conclusion and suggestions}

The study clearly reveals the importance of female in the economy of these regions. The study shows that participation of females is largely in agriculture and allied activities followed by their participation in non-agriculture sector in which they work as marginal or casual worker. The higher participation of females in non-income generating activities depicts the higher share of female participation in agriculture which has turned out to be only for subsistence generation i.e. for meeting out domestic household demand. The female labour force participation in income generating activities is largely limited to low income generating work in which females are working as marginal or casual workers.

The present study concludes two main observations from the findings of the study: (a) The decline in the female labour force participation in income generating activities with increase in household's income thus indicating towards desired policy initiatives to tap this declining female labour force with subsequent increase in family income and (b) the high level of involuntary unemployment among the females in these regions- which again demands the generation of employment opportunities for these females. As these hill rural region are agriculture dominated and lack employment opportunities the only way out to these issues is that these females could be shifted towards employment by engaging them in self employment activities or by making agriculture economically viable. Further proving marginal nature of work to the females such as through public work like under MNREGA is necessary to meet out their minimum requirements but in the long run this is not sufficient for achieving economic empowerment of females. These females could only be economically empowered if they could be made self sufficient through self employment and through involvement in higher income generating activities. Both resurrections of agriculture and increase in self employment activities demands government support in the form of delivery of adequate training and technical know-how along with credit facility. Further keeping in perspective the low social mobility of females it is important on the part of district authorities to provide the required training and skill development programs at the very vicinity of such regions. Government should also facilitate such females the use of computer and internet so that they could enhance their awareness through it. There is serious need for development of both agriculture and non- 
agriculture sector (mainly in self employment activities) for enhancing female labour force participation rate in both the sectors of the hill rural areas of the state. The benefits of increased female labour force participation could not only help in attaining women empowerment but could also help in attaining more inclusive and sustainable development of these deprived regions of the state. But in this process of development it will be detrimental in undermining the fact that these benefits could only be fully reaped only if both agriculture and non-agriculture sector develops simultaneously.

\section{References}

Bhalla, S.; Kaur, R. 2011. Labour force participation of women in India: Some facts, some queries, Working Paper No. 40 (London, Asia Research Centre, London School of Economics and Political Science)

Census of India. 2011. Govt of India, Rural-Urban Distribution Uttarakhand Series-6, Provisional population totals, Paper 2, Volume 2

Chaudhary, Ruchika \& Verick, Sher. 2015. Female Labour Force Participation in India: The Importance of Education to Access Better Jobs, Labour \& Development, Vol. 22, No. 1 Economic \& Political Weekly xlvi (32), pp 23-26.

Dighe, Anita. 2008. Women's Empowerment at the Local Level (WELL) - A study undertaken in the state of Uttarakhand, Commissioned by the Commonwealth of Learning, West Hastings Street, Vancour, Canada

Nautiyal, Annapurna. 2003. Women and Development in the Garhwal Himalayas, AJWS, Vol. 9, No. 4, 2003, pp. 93-113

Rawat, Rajiv. 2004. 'Chipko's Quiet Legacy: Forest Rights, Women's Empowerment, Peoples' Institutions, and New Urban Struggles in Uttarakhand, India' York University, Ontario, Canada (mimeo)

Rustagi, P. 2013. Changing patterns of labour force participation and employment of women in India, The Indian Journal of Labour Economics, Vol. 56, No.2.

Sekhar, C.S.C. 2007. Viable Entrepreneurial Trade for Women in Agriculture in Utttaranchal. Working Report. Agriculture Economics Research Centre, University of Delhi

Sethuraman, S.V. 1998. Gender, Informality and Poverty: A Global Review, ILO Working Paper, Geneva: ILO.

Srivastava, N.; Srivastava, R. 2010. "Women, work and employment outcomes in rural India", Economic and Political Weekly, Vol. 45, No. 28

Uttarakhand Seva Nidhi Payavaran Shiksha Sansthan. 2005. `Beyond Practical Gender Needs: Women in North-Easter and Hill States: Uttaranchal,' National Research Programme on Growth and Human Development. UNDP-Planning Commission, Government of India (mimeo). 